Review

\title{
Nutritional Modulation of Non-Alcoholic Fatty Liver Disease and Insulin Resistance
}

\author{
Hannele Yki-Järvinen \\ Received: 17 August 2015 ; Accepted: 9 October 2015 ; Published: 5 November 2015 \\ Department of Medicine, University of Helsinki, and Minerva Foundation Institute for Medical Research, \\ Haartmaninkatu 8, FI-00290 Helsinki, Finland; Hannele.Yki-Jarvinen@helsinki.fi; Tel.: +358-50-417-1664; \\ Fax: +358-94-717-1896
}

\begin{abstract}
Non-alcoholic fatty liver disease (NAFLD) covers a spectrum of disorders ranging from simple steatosis (non-alcoholic fatty liver, NAFL) to non-alcoholic steatohepatitis (NASH) and cirrhosis. NAFL increases the risk of liver fibrosis. If the liver is fatty due to causes of insulin resistance such as obesity and physical inactivity, it overproduces glucose and triglycerides leading to hyperinsulinemia and a low high-density lipoprotein (HDL) cholesterol concentration. The latter features predispose to type 2 diabetes and cardiovascular disease (CVD). Understanding the impact of nutritional modulation of liver fat content and insulin resistance is therefore of interest for prevention and treatment of NAFLD. Hypocaloric, especially low carbohydrate ketogenic diets rapidly decrease liver fat content and associated metabolic abnormalities. However, any type of caloric restriction seems effective long-term. Isocaloric diets containing $16 \%-23 \%$ fat and $57 \%-65 \%$ carbohydrate lower liver fat compared to diets with $43 \%-55 \%$ fat and $27 \%-38 \%$ carbohydrate. Diets rich in saturated (SFA) as compared to monounsaturated (MUFA) or polyunsaturated (PUFA) fatty acids appear particularly harmful as they increase both liver fat and insulin resistance. Overfeeding either saturated fat or carbohydrate increases liver fat content. Vitamin E supplementation decreases liver fat content as well as fibrosis but has no effect on features of insulin resistance.
\end{abstract}

Keywords: saturated fat; carbohydrate; fructose; liver fat; steatosis

\section{Introduction}

NAFLD Definitions. Non-alcoholic fatty liver disease (NAFLD) is defined as steatosis (over 5\% to $10 \%$ of hepatocytes have macroscopic steatosis) [1], which is not due to excess use of alcohol (defined in the most recent guideline from American Association for the Study of Liver Diseases as alcohol consumption exceeding 21 drinks on average per week in men and 14 drinks in women) [2], or other conditions as determined by careful family and medical history, and laboratory tests to exclude at least steatosis due to viral and autoimmune causes and iron overload [2]. NAFLD is usually asymptomatic and most patients have normal transaminases (ALT $<30-40 \mathrm{U} / \mathrm{L}$ for men and $<20-30 \mathrm{U} / \mathrm{L}$ for women) [3,4] although NAFLD is the most common cause of incidentally discovered elevated liver function tests [5]. Some patients with NAFLD have non-alcoholic steatohepatitis (NASH), which can only be diagnosed by a liver biopsy. NASH is characterized in addition to steatosis by ballooning necrosis in the vicinity of steatotic hepatocytes, mild inflammation and possibly fibrosis [6]. Fibrosis is staged on a scale from 0 to 4 , where 4 is cirrhosis [6]. While NAFLD is as common as the metabolic syndrome (MetS), the prevalence estimates of NASH range from 3\% to $6 \%[7,8]$. 
Heterogeneity of NAFLD. Although NAFLD is commonly observed in insulin-resistant obese and sometimes insulin-resistant non-obese subjects with the MetS ("Metabolic NAFLD") (Figure 1), at least two common genetic forms of NAFLD also exist. An allele in PNPLA3 (rs738409[G], encoding I148M, prevalence $30 \%-50 \%$ worldwide) increases liver fat ("PNPLA3 NAFLD") and the risk of hepatic inflammation and fibrosis, cirrhosis and hepatocellular carcinoma (HCC) [9-12]. "PNPLA3 NAFLD" is not associated with insulin resistance [10,13]. Another fairly common polymorphism, an E167K variant in (E167K) in TM6SF2 (prevalence 15\%) also confers susceptibility to NAFLD ("TM6SF2 NAFLD") [14]. Carriers with "TM6SF2 NAFLD" are at increased risk of NASH but are not insulin-resistant and their circulating concentrations of triglycerides are normal or subnormal rather than increased $[14,15]$. Hepatic knockdown of TM6SF2 decreases very low-density lipoprotein (VLDL) secretion $[14,16]$.

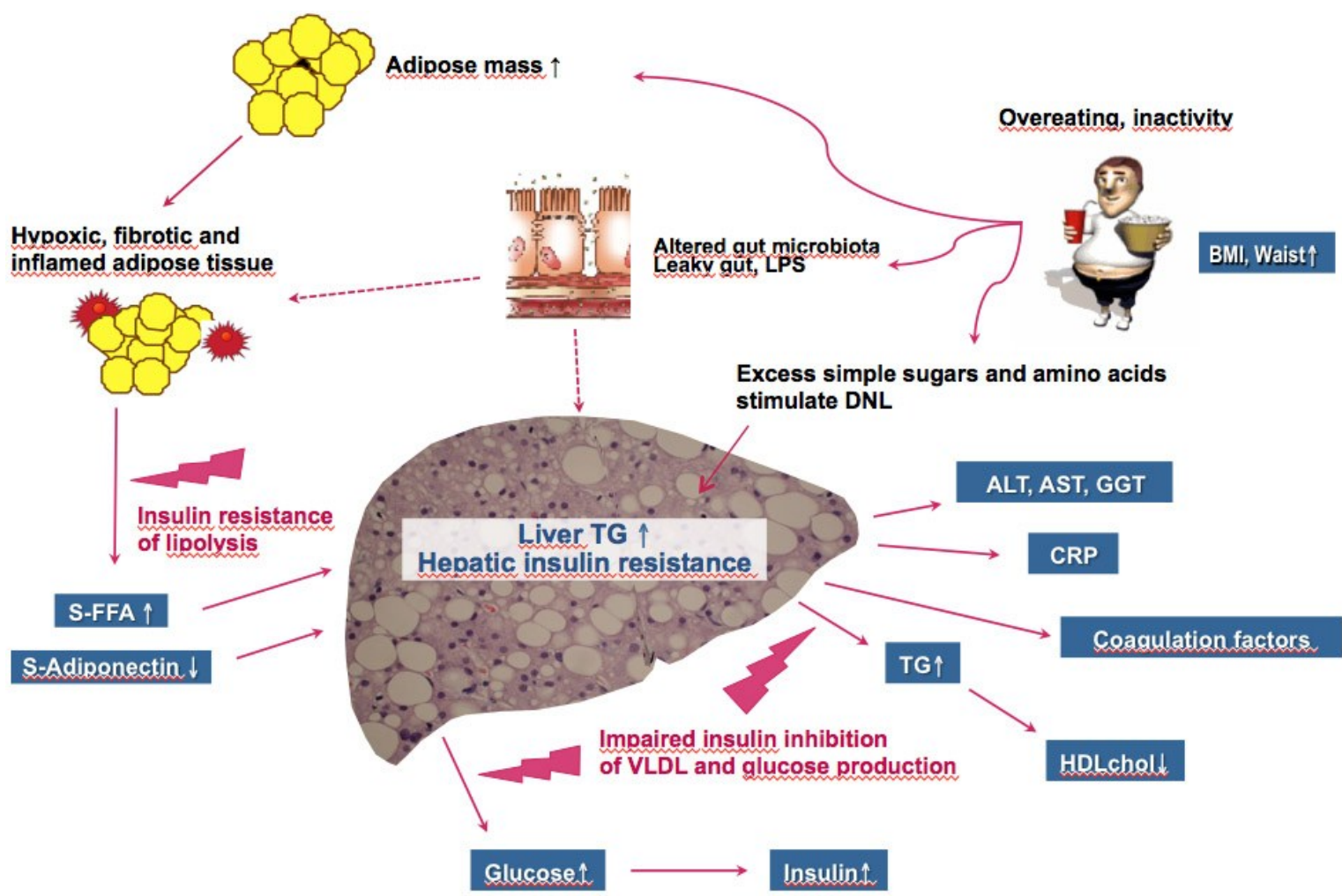

Figure 1. Pathophysiology of "Metabolic NAFLD", which causes and consequences resemble those of the insulin resistance/metabolic syndrome (MetS). Overeating and physical inactivity predispose to both conditions. Excess glucose, fructose and amino acids are converted to triglyceride (TG) in the liver via de novo lipogenesis (DNL), which pathway is increased in NAFLD [17]. Alterations in gut microbiota in obesity increase gut permeability to bacterial components such as lipopolysaccharide (LPS), which may contribute to inflammation in both adipose tissue and the liver [18]. Overeating leads to adipose tissue expansion, hypoxia, increased fibrosis and cell death. Dead adipocytes are surrounded by macrophages, which produce cytokines such as tumor-necrosis alpha and chemokines such as monocyte chemoattractant protein-1. This impairs the ability of insulin to inhibit lipolysis i.e., inhibit release of free fatty acids (FFA) and leads to deficiency of the insulin-sensitizing cytokine adiponectin. The latter two changes promote synthesis of intrahepatocellular TG. The ability of insulin to suppress glucose and VLDL production is impaired resulting in mild hyperglycemia and hyperinsulinemia, hypertriglyceridemia (TG $\uparrow$ ) and a low HDL cholesterol concentration (HDL chol $\downarrow$ ). The fatty liver also overproduces many other factors such as the liver enzymes alanine aminotransferase (ALT), aspartate aminotransferase (AST) and gamma-glutamyltransferase (GGT), $\mathrm{C}$-reactive protein (CRP) and coagulation factors [13]. 
While the PNPLA3 or TM6SF2 variants increase liver fat content and the risk of NASH, they do not increase the risk of type 2 diabetes or cardiovascular disease (CVD), consistent with lack of insulin resistance. This implies that the objective of treatment of patients with "PNPLA3 NAFLD" and TM6SF2 NAFLD' is to prevent liver disease rather than metabolic complications. However, the same person may have "Metabolic NAFLD" and NAFLD attributable to genetic variants [15]. The etiology of NAFLD might impact the response of the liver to dietary interventions (vide infra).

Significance. Patients with NAFLD have an increased risk of mortality from CVD, cirrhosis and hepatocellular carcinoma (HCC) [19]. Recent prospective studies with paired liver biopsies contradicted the old dogma that NAFL is benign by showing that NAFL can progress to NASH and clinically significant fibrosis [8]. A recent meta-analysis of 411 patients with biopsy-proven NAFLD defined the average rate of progression. The rate of 1 stage fibrosis progression was 14.3 years for NAFL and 7.1 years for patients with NASH [20]. Given this slow rate of progression and lack of approved pharmacotherapies for NAFLD, there is abundant time for lifestyle changes to impact progression of NAFLD.

NAFLD and insulin resistance. The liver is the site of production of two key components of the insulin resistance/MetS, fasting serum glucose and very-low density lipoprotein (VLDL), which contains most of circulating triglycerides. In subjects with NAFLD attributable to being overweight and inactive ("Metabolic NAFLD"), the ability of insulin to normally suppress production of glucose and VLDL is impaired [21,22]. Hyperglycemia stimulates insulin secretion and thereby induces hyperinsulinemia (Figure 1). The high concentration of VLDL leads to lowering of high-density lipoprotein (HDL) cholesterol and to generation of small dense LDL particles, which are known to be highly atherogenic (see [23] for review). The liver, once fatty, also overproduces many other markers of cardiovascular risk such as C-reactive protein and coagulation factors [13] (Figure 1).

The ensuing review is focused on analyzing studies comparing effects of different diets on liver fat content and insulin sensitivity in the face of a similar total caloric content. The studies are subgrouped based on their caloric content (isocaloric/hypocaloric/hypercaloric). Studies comparing low fat/high carbohydrate to high fat/low carbohydrate diets are shown in Table 1 and studies comparing effects of different types of sugars on liver fat content and insulin sensitivity in Table 2. The influence of dietary fat on liver fat accumulation has recently been analyzed in an excellent review [24].

Table 1. Studies comparing effects of low fat-high carbohydrate and high fat-low carbohydrate on liver fat and insulin sensitivity.

\begin{tabular}{|c|c|c|c|c|c|c|c|c|c|}
\hline$N$ & $\begin{array}{l}\text { BMI } \\
\left(\mathrm{kg} / \mathrm{m}^{2}\right)\end{array}$ & $\begin{array}{l}\text { Age } \\
\text { (Years) }\end{array}$ & Duration & Design & Cal & $\%$ Fat $\%$ Carb & $\begin{array}{c}\text { Liver Fat } \\
(\%) \\
\text { Before-After }\end{array}$ & $\begin{array}{c}\text { Insulin } \\
\text { Sensitivity } \\
\text { Method Change }\end{array}$ & $\begin{array}{c}\text { Year of } \\
\text { Reference }\end{array}$ \\
\hline 10 & 33 & 43 & 2 weeks & $\mathrm{C}$ & ISO & $\begin{array}{l}16 \% 61 \% \\
56 \% 31 \%\end{array}$ & $\begin{array}{l}10-8^{*} \\
10-13\end{array}$ & $\begin{array}{l}\text { fS-Ins Improved } \\
\text { Worsened }\end{array}$ & 2005 [25] \\
\hline 20 & 29 & 34 & 3 weeks & $\mathrm{P}$ & ISO & $\begin{array}{l}20 \% \text { 65\% } \\
55 \% 30 \%\end{array}$ & $\begin{array}{c}4.0-3.5 * \\
2.2-2.6\end{array}$ & $\underset{\text { NS }}{\text { Clamp NS }}$ & 2011 [26] \\
\hline 61 & 31 & $30-65$ & $\begin{array}{c}10 \\
\text { weeks }\end{array}$ & $\mathrm{P}$ & ISO & $\begin{array}{l}40 \%{ }^{\text {a }} 39 \% \\
43 \%^{\text {b }} 40 \%\end{array}$ & $\begin{array}{c}3.2-2.3 * \\
3.2-3.5\end{array}$ & $\begin{array}{l}\text { fS-Ins NS } \\
\text { Worsened }\end{array}$ & 2012 [27] \\
\hline 45 & 30 & $35-70$ & 8 weeks & $\mathrm{P}$ & ISO & $\begin{array}{c}28 \% 53 \% \\
42 \%{ }^{c} 40 \%\end{array}$ & $\begin{array}{l}17.7-16.1 \\
7.4-5.2 \downarrow\end{array}$ & $\begin{array}{c}\text { fS-Ins NS } \\
\text { NS }\end{array}$ & 2012 [28] \\
\hline 35 & 27 & 69 & 4 weeks & $\mathrm{P}$ & ISO & $\begin{array}{l}23 \% 57 \% \\
43 \% 38 \%\end{array}$ & $\begin{array}{c}2.2-1.7 \downarrow \\
1.2-1.6\end{array}$ & $\begin{array}{c}\text { fS-Ins NS } \\
\text { NS }\end{array}$ & 2013 [29] \\
\hline
\end{tabular}


Table 1. Cont.

\begin{tabular}{|c|c|c|c|c|c|c|c|c|c|}
\hline 12 & 32 & 55 & 6 weeks & C & ISO & $\begin{array}{l}21 \% \text { d } 49 \% \\
44 \% \text { e } 34 \%\end{array}$ & $\begin{array}{c}11.2-10.0 \\
14.2-8.6 \downarrow\end{array}$ & $\begin{array}{l}\text { Clamp NS * } \\
\text { Improved }\end{array}$ & 2013 [30] \\
\hline 22 & 37 & 44 & $\begin{array}{c}11 \\
\text { weeks }\end{array}$ & $\mathrm{P}$ & HYPO & $\begin{array}{l}20 \% 65 \% \\
75 \% 10 \%\end{array}$ & $\begin{array}{l}11.2-6.2 \downarrow \\
12.4-7.7 \downarrow\end{array}$ & $\begin{array}{l}\text { fS-Ins Improved * } \\
\text { Improved }\end{array}$ & 2009 [31] \\
\hline 18 & 35 & 45 & 2 weeks & $\mathrm{P}$ & HYPO & $\begin{array}{c}34 \% 50 \% \\
59 \% 8 \%\end{array}$ & $\begin{array}{l}19-8.6 \downarrow * \\
22-15.8 \downarrow\end{array}$ & $\begin{array}{l}\text { fS-Ins NS } \\
\text { NS }\end{array}$ & 2011 [32] \\
\hline 102 & 32 & 45 & $\begin{array}{c}6 \\
\text { months }\end{array}$ & $\mathrm{P}$ & HYPO & $\begin{array}{l}\text { "reduced fat" } \\
\text { "reduced carb" }\end{array}$ & $\begin{array}{l}9.6-5.6 \downarrow \\
7.6-4.0 \downarrow\end{array}$ & $\begin{array}{l}\text { fS-Ins Improved } \\
\text { Improved }\end{array}$ & 2011 [33] \\
\hline 39 & 23 & 25 & 7 days & $\mathrm{P}$ & HYPER & $\begin{array}{l}+ \text { fructose } \\
+ \text { fat }\end{array}$ & $\begin{array}{l}12-14^{\mathrm{h}} \uparrow \\
11-21^{\mathrm{h}} \uparrow\end{array}$ & $\begin{array}{l}\text { fS-Ins NS } \\
\text { NS }\end{array}$ & 2010 [34] \\
\hline 39 & $18-27$ & $20-38$ & 7 weeks & $\mathrm{P}$ & HYPER & $\begin{array}{l}40 \%{ }^{\text {f }} 43 \% \\
36 \%{ }^{g} 48 \%\end{array}$ & $\begin{array}{l}0.75-0.79 \\
0.96-1.5^{*}\end{array}$ & $\begin{array}{l}\text { fS-Ins NS } \\
\text { NS }\end{array}$ & 2014 [35] \\
\hline
\end{tabular}

Abbreviations: $\mathrm{N}=$ number of completers, BMI = body mass index, yrs = years, wks = weeks, mos = months, $\mathrm{C}=$ crossover, $\mathrm{P}=$ parallel, $\mathrm{Cal}=$ caloric content relative to baseline diet, $\mathrm{ISO}=$ isocaloric, $\mathrm{HYPO}=$ hypocaloric, HYPER $=$ hypercaloric, $\%$ Fat $\%$ Carb $=\%$ fat and $\%$ carbohydrate. $\uparrow$ Significant increase, $\downarrow$ significant decrease before vs. after, ${ }^{*}$ significant difference in change between the two different diets, fS-Ins = fasting serum insulin, Clamp = euglycemic hyperinsulinemic insulin clamp technique. ${ }^{a}=10 \%$ SFA, 13\% POLY; $\mathrm{b}=20 \%$ SFA, $8 \%$ POLY; ${ }^{c}$ enriched with MONO, saturated fat as in control arm; ${ }^{\mathrm{d}} 36 \% \mathrm{SFA} / 39 \% \mathrm{MONO} / 24 \%$ POLY; ${ }^{\mathrm{e}} 31 \%$ SFA/51\% MONO/18\% POLY; ${ }^{\mathrm{f}} 11 \%$ SFA and $13 \%$ POLY; $\mathrm{g} 16 \%$ SFA and $4 \%$ POLY, ${ }^{\mathrm{h}}$ Units for liver fat $\mathrm{mmol} / \mathrm{kg}$. NS = no significant change. Changes in liver fat in the table calculated based on mean changes. + fructose $=$ addition of 3.5 grams $/$ day of fructose $/ \mathrm{kg}$ fat free mass, + fat $=$ addition of $30 \%$ of total calories as fat.

Table 2. Effects of fructose as compared to other carbohydrates on liver fat and insulin sensitivity.

\begin{tabular}{|c|c|c|c|c|c|c|c|c|c|}
\hline$N$ & $\begin{array}{c}\text { BMI } \\
\left(\mathrm{kg} / \mathrm{m}^{2}\right)\end{array}$ & $\begin{array}{l}\text { Age } \\
\text { (Years) }\end{array}$ & Duration & Design & Cal & $\begin{array}{c}\text { Fructose Diet Other } \\
\text { CARB Diet }\end{array}$ & $\begin{array}{l}\text { Liver Fat } \\
(\%) \\
\text { Before-After }\end{array}$ & $\begin{array}{c}\text { Insulin } \\
\text { Sensitivity } \\
\text { Method Change }\end{array}$ & $\begin{array}{c}\text { Year of } \\
\text { Reference }\end{array}$ \\
\hline 32 & 29 & 34 & 2 weeks & $\mathrm{P}$ & ISO & $\begin{array}{l}\text { FRU } 25 \%{ }^{\mathrm{b}} \\
\text { GLU } 25 \%^{\mathrm{b}}\end{array}$ & $\begin{array}{l}7.2-7.5 \\
8.0-7.9\end{array}$ & $\begin{array}{c}\text { fS-Ins Worsened } \\
\text { NS }^{\mathrm{c}}\end{array}$ & 2013 [36] \\
\hline 11 & $75 \mathrm{~kg}^{\mathrm{b}}$ & 25 & 7 days & C & HYPER & $\begin{array}{l}\text { FRU 35\% } \\
\text { GLU } 35 \%{ }^{b}\end{array}$ & $\begin{array}{l}2.1-3.2 \uparrow \\
2.1-3.3 \uparrow\end{array}$ & $\begin{array}{l}\text { fS-Ins NS } \\
\text { NS }\end{array}$ & 2010 [37] \\
\hline 20 & 25 & 30 & $\begin{array}{c}10 \\
\text { weeks }\end{array}$ & $\mathrm{P}$ & HYPER & $\begin{array}{l}\text { FRU +600 cal/day } \\
\text { GLU +600 cal/day }\end{array}$ & $\begin{array}{l}1.3-1.8 \\
1.6-2.1\end{array}$ & $\begin{array}{l}\text { fS-Ins NS } \\
\text { NS }\end{array}$ & 2012 [38] \\
\hline 22 & 32 & 39 & $\begin{array}{c}6 \\
\text { months }\end{array}$ & $\mathrm{P}$ & HYPER & $\begin{array}{l}\text { SSB }+430 \mathrm{cal} / \text { day } \\
\text { Milk }+454 \mathrm{cal} / \text { day }\end{array}$ & $\begin{array}{l}3.7-5.0 \uparrow^{*} \\
12.7-11.6\end{array}$ & $\begin{array}{l}\text { fS-Ins NS } \\
\text { NS }\end{array}$ & 2012 [39] \\
\hline 64 & 27 & 42 & $\begin{array}{c}10 \\
\text { weeks }\end{array}$ & $\mathrm{P}$ & HYPER & $\begin{array}{c}\text { HFCS } 8 \%-30 \%{ }^{b} \\
\text { SUCROSE } 8 \%-30 \%{ }^{\text {b }}\end{array}$ & $\begin{array}{l}11.8-13.7 \\
14.9-13.0\end{array}$ & $\begin{array}{l}\text { fS-Ins NS } \\
\text { NS }\end{array}$ & 2013 [40] \\
\hline 32 & 29 & 34 & 2 weeks & $\mathrm{P}$ & HYPER & $\begin{array}{l}\text { FRU }+25 \% \text { b } \\
\text { GLU }+25 \% \text { b }\end{array}$ & $\begin{array}{l}7.2-8.9 \uparrow \\
8.0-10.1 \uparrow\end{array}$ & $\begin{array}{l}\text { fS-Ins NS } \\
\text { NS }\end{array}$ & 2013 [36] \\
\hline 28 & 22 & 23 & $\begin{array}{l}6-7 \\
\text { days }\end{array}$ & $\mathrm{P}$ & HYPER & $\begin{array}{l}\text { FRU } 3 \mathrm{~g} / \mathrm{kg} \text { day } \\
\text { GLU } 3 \mathrm{~g} / \mathrm{kg} \text { day }\end{array}$ & $\begin{array}{l}9.0-18.5 \uparrow \\
12.9-16.1\end{array}$ & $\begin{array}{c}\text { fS-Ins Worsened } \\
\text { NS }\end{array}$ & 2013 [41] \\
\hline
\end{tabular}

Abbreviations: $N$ = number of completers, BMI = body mass index, yrs = years, wks = weeks, mos = months, $\mathrm{d}=$ day, $\mathrm{C}=$ crossover, $\mathrm{P}=$ parallel, $\mathrm{Cal}=$ caloric content relative to baseline diet, $\mathrm{FRU}=$ fructose, $\mathrm{HFCS}=\mathrm{high}$ fructose corn syrup, GLU = glucose, NS = no significant change (before $v$ s. after diet), ISO = isocaloric, HYPER $=$ hypercaloric, SSB = sugar sweetened beverage, $\uparrow$ Significant increase after vs. before, ${ }^{*}$ significant difference in change between the two diets, fS-Ins = fasting serum insulin, Clamp = euglycemic hyperinsulinemic insulin clamp technique. ${ }^{\mathrm{a}}=$ body weight, ${ }^{\mathrm{b}}=\%$ of total energy intake, ${ }^{\mathrm{c}} \mathrm{NS}=$ no significant change. Changes in liver fat in the table calculated based on mean changes.

\section{Effect of Different Diets on NAFLD and Insulin Sensitivity}

Overall, as shown by Figure 2, the energy content of the diet is the most important factor influencing liver fat content, which is why weight loss is recommended to all overweight or obese patients with NAFLD [2] Given that conventional hypocaloric diets are unable to achieve persistent weight loss in morbidly obese patients, bariatric surgery is becoming increasingly important in the management of NAFLD. Weight loss following bariatric surgery induces improvements in steatosis, necroinflammation and fibrosis and insulin resistance. NASH is not a contraindication for surgery unless complicated by cirrhosis or portal hypertension (see [42-45] for reviews). 

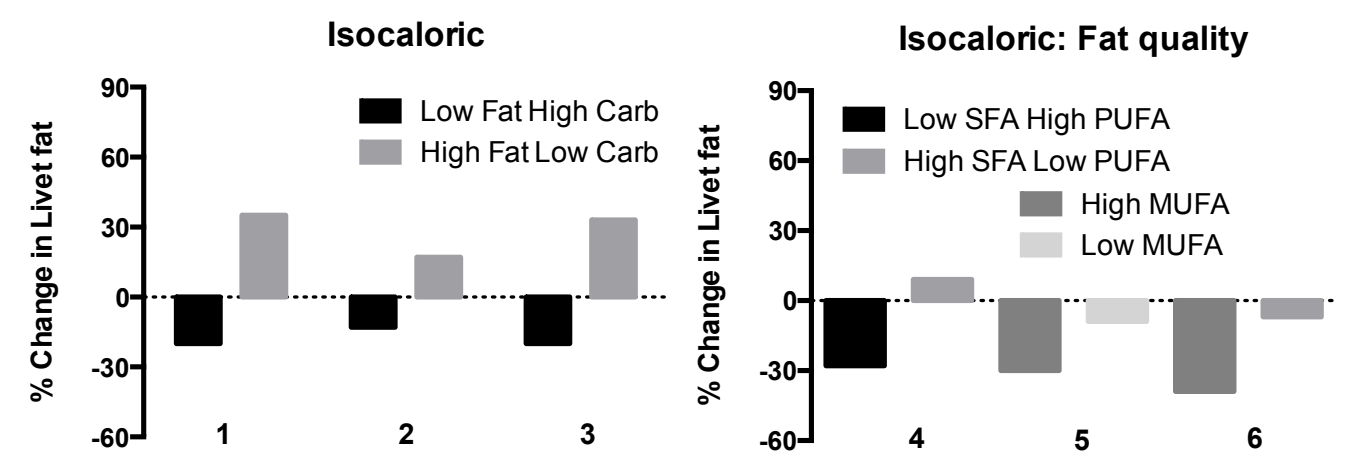

Hypocaloric
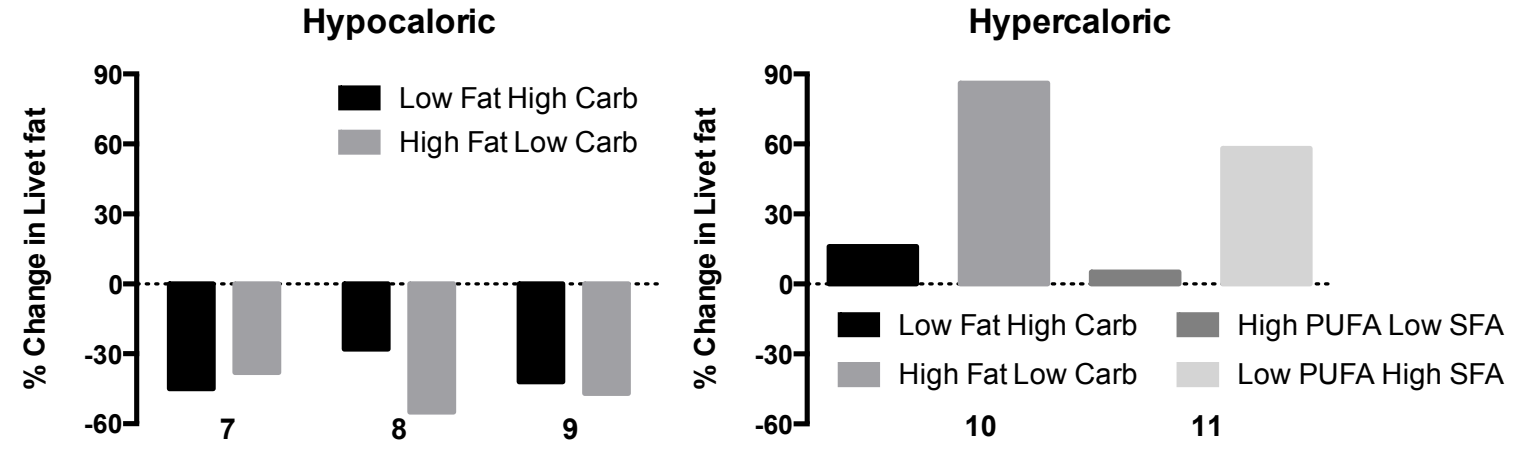

Figure 2. Effect of dietary composition on liver fat content, expressed as relative change from baseline measured by proton magnetic resonance spectroscopy $\left({ }^{1} \mathrm{H}-\mathrm{MRS}\right)$. Diets comparing isocaloric low fat/high carbohydrate (Low Fat High Carb) to high fat/low-carbohydrate (High Fat Low Carb) diets (upper panel on the left, $1=$ [25], $2=$ [26], $3=$ [29]), isocaloric low saturated fat/high polyunsaturated fat (Low SFA High PUFA) to high saturated/low polyunsaturated fat (High SFA Low PUFA) or isocaloric high monounsaturated (High MUFA) to low monounsaturated fat (Low MUFA) (upper panel on the right, $4=$ [27], $5=$ [28], $6=$ [30]) diets. The bottom panels depict effects of hypocaloric Low Fat High Carb compared to High Fat Low Carb diets (panel on the left, $7=[31], 8=[32], 9=[33]$ ) and hypercaloric Low Fat High Carb vs. High Fat Low Carb $(10=[34])$ and High PUFA Low SFA vs. Low PUFA High SFA $(11=[35])$ diets on liver fat content.

Genetic etiology of NAFLD may influence the response to a hypocaloric diet. We observed a greater reduction in liver fat in response to a six-day ketogenic diet in subjects homozygous for the PNPLA3 I148M variant as compared to non-carriers [46]. This finding was recently confirmed in a larger post hoc analysis of 154 patients [47]. In this study, liver fat content measured by ${ }^{1} \mathrm{H}-\mathrm{MRS}$ decreased significantly and 3-fold more in subjects with the GG as compared to CC genotype (11.3\% vs. $3.7 \%)$.

Isocaloric comparisons (Figure 2, Table 1). In three of the studies shown in Table 1, a low fat ( $16 \%-23 \%$ of total calories)-high carbohydrate $(57 \%-65 \%)$ diet was compared to a low carbohydrate $(31 \%-38 \%)$-high fat $(43 \%-56 \%)$ diet. Quite consistently, liver fat content decreased during the low fat-high carbohydrate diet and increased during the high fat-low carbohydrate diet (Figure 2). The high fat rather than the low carbohydrate component in the diet is the likely cause of the increase in liver fat since low carbohydrate diets seem particularly effective in reducing liver fat (vide infra).

In the isocaloric comparisons of a high fat-low carbohydrate vs. a low fat-high carbohydrate diets, there were no convincing changes in insulin sensitivity. However, the studies were small and hepatic insulin sensitivity was not assessed directly.

Hypocaloric comparisons (Figure 2, Table 1). Even small amounts of weight loss decrease liver fat content. For example, two to six days of a hypocaloric diet $(-1000 \mathrm{cal} /$ day $)$ decreases liver fat by $30 \%-45 \%$ in the face of trivial amounts of weight loss [31,46]. Two studies have compared changes in liver fat during ketogenic low-carbohydrate and standard hypocaloric diets in the face of 
similar decrease in body weight. In these studies lasting two days and two weeks, the ketogenic diet decreased liver fat content more than the standard hypocaloric diet [31,32]. However, in the study of Kirk et al [31], repeat study of the subjects after 11 weeks no longer showed a significant difference in the decrease in liver fat content (Table 1). Patients are commonly placed on a hypocaloric diet prior to bariatric surgery to reduce liver volume. Low-carbohydrate ketogenic diets decrease liver volume more than standard hypocaloric diets, most likely because low carbohydrate diets rapidly deplete liver glycogen [48].

Hypercaloric comparisons (Figure 2, Table 1). Rosqvist et al. [35] compared a diet enriched with SFAs at the expense of PUFAs to a diet rich in PUFAs but poor in SFAs. The extra calories were served as similar looking muffins. Macronutrient composition of the diets was comparable. After seven weeks, weight gain was identical in both groups $(1.6 \mathrm{~kg})$ but liver fat content had increased in the high SFA-low PUFA group but not in the other group (Figure 2). In the other study including 39 subjects, seven days of high fat overfeeding ( $30 \%$ caloric excess from fat) increased liver fat content by $86 \%$ while fructose overfeeding only increased liver fat by $16 \%$ [34]. The difference in the increments in liver fat was not statistically significant.

\section{Effect of Type of Fat on NAFLD and Insulin Sensitivity}

High SFA-Low PUFA vs. Low SFA-High PUFA. In the largest of the isocaloric studies [27], macronutrient composition was maintained essentially unchanged but the quality of the fat differed. Liver fat content decreased during the diet high in PUFA and low in SFA compared to the high SFA-low PUFA diet. This suggests that either SFAs or PUFAs regulate liver content. Fasting insulin increased in the high SFA-low PUFA group and remained unchanged in the high PUFA-low SFA group (Table 1). This result supports previous data such as the KANWU study in 162 subjects showing that isocaloric substitution of dietary SFA for MUFA for three months impairs insulin sensitivity and lowers LDL cholesterol [49]. The impairment in insulin sensitivity was due to the SFA rather than the MUFA diet, consistent with several smaller studies [50].

High MUFA. Two isocaloric studies compared the effect of increasing total fat content using mainly MUFAs [28,30]. Although total fat content was higher both in the study of Bozzetto et al. (42\% vs. 28\%) [28] and the study of Ryan et al. (44\% vs. 21\%) [30], liver fat content decreased with the diets enriched with MUFAs. However, the lower carbohydrate content of the MUFA could also have contributed to the lowering of liver fat content.

As summarized in an extensive review, MUFAs do not impair insulin sensitivity as do SFAs [50]. For example, MUFAs did not affect insulin sensitivity In the "KANWU" study [49] or in the more recent large 24-week "RISCK" study where subjects were randomized to consume either a high SFA or a high MUFA diet [51].

\section{Effect of Type of Carbohydrate on NAFLD and Insulin Sensitivity}

In contrast to glucose, fructose bypasses the rate-limiting step of glycolysis catalyzed by phosphofructokinase in the liver (see [52] for review). It therefore can provide more substrates for de novo lipogenesis (DNL) than glucose and could be predicted to increase intrahepatic triglycerides and VLDL production more than glucose [52]. Five studies have compared effects of fructose or high fructose corn syrup to glucose or sucrose overfeeding on liver fat content (Table 2). Of these, only one short-term study found fructose but not glucose to increase liver fat [41]. Fructose did not induce insulin resistance in any of the studies. Maersk et al. found six months of sugar-sweetened beverage (SSB) to increase liver fat more than milk [39]. However, milk contains only half as much carbohydrate as SSB the rest being protein and fat. These data and the systematic review and meta-analysis by Chung et al. [53] imply that there is not enough evidence to draw conclusions regarding effects of fructose and HFCS compared to sucrose consumption on NAFLD. However, even if a difference in changes in liver fat between the fructose and glucose was not demonstrated, excess carbohydrate calories increased liver fat content in many of the comparative studies as has also been found in high 
sugar overfeeding studies without another carbohydrate comparator arm [34,46,54,55]. Although not found in studies quantifying liver fat (Table 2$)$, isocaloric fructose ( $25 \%$ of total daily caloric intake for 10 weeks) as compared to glucose consumption has been shown to impair insulin sensitivity [56].

\section{Effect of Other Nutritional Interventions on NAFLD and Insulin Sensitivity}

Vitamin E. Vitamin E is an antioxidant which, at a dose of 800 IU/day was shown to improve steatosis, inflammation and ballooning in a 96-week trial in NASH [57]. The vitamin E arm included 84 subjects and placebo arm 83 subjects with NASH but with no diabetes. Vitamin E did not change insulin sensitivity or lipid concentrations. Vitamin E at a dose of $800 \mathrm{IU} /$ day compared to placebo has also been shown to resolve NASH in children aged 8-17 years with biopsy-proven NAFLD [58].

\section{Mechanisms Underlying Nutritional Modulation of Liver Fat Content in Humans}

Fatty acids in intrahepatocellular triglycerides can originate from adipose tissue lipolysis, DNL, uptake of fatty acids from chylomicron remnants and from fatty acids released during intravascular hydrolysis of triglyceride-rich lipoproteins [59]. Studies using stable isotopes to trace pathways of hepatic triglyceride synthesis have shown that both adipose tissue lipolysis and DNL are increased in NAFLD [17,60-62] (Figure 1).

Nutritional modulation of lipolysis. Short-term fasting lowers glucose and insulin concentrations and increases the rate of basal lipolysis $[46,63,64]$. The increase rate of lipolysis, as measured by a stable isotope glycerol tracer is closely related to decreases in fasting insulin [63]. After an overnight fast, approximately $40 \%$ of the FFA are taken up by the splanchnic bed. These FFA can be used for ketone body production, oxidation or secreted in VLDL. Over six days of a hypocaloric low-carbohydrate diet, liver fat decreases despite an increase in lipolysis as FFA as are oxidized and used for ketone body production rather than stored as triglycerides in the liver [46]. Whether these changes were due to the decrease in energy content of the diet or the low carbohydrate content is unclear as very few data comparing effects of different diets on liver fat content and lipolysis are available. In the study of Haufe et al. comparing low and high carbohydrate hypocaloric diets [33], fasting FFA increased during the low carbohydrate diet but remained unchanged during the high carbohydrate diet [33]. As reviewed by Jensen et al., isoenergetic diets do not seem to change basal FFA flux or oxidation [65].

Nutritional modulation of DNL. Short-term overfeeding with carbohydrate as compared to fat markedly increases DNL [66,67], which in relative terms is the most increased pathway in NAFLD [17]. However, in absolute terms, lipolysis is the main source of intrahepatocellular triglycerides both in normal subjects and those with NAFLD [17]. There are no studies comparing effects of different diets on liver fat content and DNL.

\section{Concluding Remarks}

Studies comparing effects of different diets on liver fat content and insulin sensitivity have included a low number of subjects and lasted a maximum of six months. Nevertheless, some conclusions seem justified. Hypocaloric diets decrease while overfeeding increases liver fat content. Low fat-high carbohydrate as compared to high fat-low carbohydrate diets seem to decrease liver fat and enhance insulin sensitivity in the face of similar isocaloric or hypocaloric total caloric contents. The deleterious effect of high fat seems to be due to SFAs while PUFA or MUFA containing diets may be beneficial. Hypercaloric high carbohydrate diets increase liver fat content, but there are no convincing data to show fructose is worse than glucose, although the metabolism of fructose can be predicted to have more harmful effects on the liver than glucose. The sources of intrahepatocellular triglycerides or impact of genetic forms of NAFLD during different diets have not been systematically studied. Given the high prevalence of both "Metabolic NAFLD", "PNPLA3 NAFLD" and "TM6SF2 NAFLD" and the associated risks of type 2 diabetes and CVD ("Metabolic NAFLD") and advanced liver disease (all forms increase the risk of NASH, cirrhosis and HCC), there is a need for large 
multicenter studies with sufficient numbers of patients to define the composition of a diet which can prevent or reverse these problems.

Acknowledgements: This study was supported by grants from the EU/EFPIA Innovative Medicines Initiative Joint Undertaking (EMIF grant no. 115372, HY), the EPoS (Elucidating Pathways of Steatohepatitis) consortium funded by the Horizon 2020 Framework Program of the European Union under Grant Agreement 634413.

Conflicts of Interest: The author declares no conflict of interest.

\section{Abbreviations}

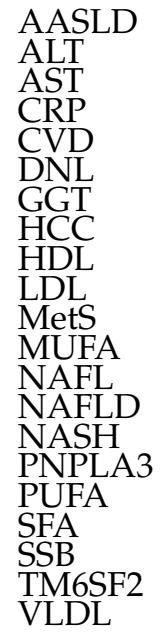

\author{
American Association for the Study of Liver Diseases \\ alanine aminotransferase \\ Aspartate aminotransferase \\ C-reactive protein \\ cardiovascular disease \\ de novo lipogenesis \\ gamma-glutamyltransferase \\ hepatocellular carcinoma \\ high-density lipoprotein \\ low-density lipoprotein \\ metabolic syndrome \\ monounsturated fatty acid \\ non-alcoholic fatty liver \\ non-alcoholic fatty liver disease \\ non-alcoholic steatohepatitis \\ patatin-like phospholipase domain containing 3 \\ polyunsaturated fatty acid \\ saturated fatty acid \\ sugar-sweetened beverages \\ transmembrane 6 superfamily member 2 \\ very low-density lipoprotein
}

\section{References}

1. Neuschwander-Tetri, B.A.; Caldwell, S.H. Nonalcoholic steatohepatitis: Summary of an AASLD Single Topic Conference. Hepatology 2003, 37, 1202-1219. [CrossRef] [PubMed]

2. Chalasani, N.; Younossi, Z.; Lavine, J.E.; Diehl, A.M.; Brunt, E.M.; Cusi, K.; Charlton, M.; Sanyal, A.J. The diagnosis and management of non-alcoholic fatty liver disease: Practice guideline by the American Gastroenterological Association, American Association for the Study of Liver Diseases, and American College of Gastroenterology. Gastroenterology 2012, 142, 1592-1609. [CrossRef] [PubMed]

3. Browning, J.D.; Szczepaniak, L.S.; Dobbins, R.; Nuremberg, P.; Horton, J.D.; Cohen, J.C.; Grundy, S.M.; Hobbs, H.H. Prevalence of hepatic steatosis in an urban population in the United States: Impact of ethnicity. Hepatology 2004, 40, 1387-1395. [CrossRef] [PubMed]

4. Kotronen, A.; Westerbacka, J.; Bergholm, R.; Pietilainen, K.H.; Yki-Jarvinen, H. Liver fat in the metabolic syndrome. J. Clin. Endocrinol. Metab. 2007, 92, 3490-3497. [CrossRef] [PubMed]

5. Clark, J.M.; Brancati, F.L.; Diehl, A.M. The prevalence and etiology of elevated aminotransferase levels in the United States. Am. J. Gastroenterol. 2003, 98, 960-967. [CrossRef] [PubMed]

6. Brunt, E.M.; Kleiner, D.E.; Wilson, L.A.; Belt, P.; Neuschwander-Tetri, B.A.; Network, N.C.R. Nonalcoholic fatty liver disease (NAFLD) activity score and the histopathologic diagnosis in NAFLD: Distinct clinicopathologic meanings. Hepatology 2011, 53, 810-820. [CrossRef] [PubMed]

7. Vernon, G.; Baranova, A.; Younossi, Z.M. Systematic review: The epidemiology and natural history of non-alcoholic fatty liver disease and non-alcoholic steatohepatitis in adults. Aliment. Pharmacol. Ther. 2011, 34, 274-285. [CrossRef] [PubMed]

8. Anstee, Q.M.; Targher, G.; Day, C.P. Progression of NAFLD to diabetes mellitus, cardiovascular disease or cirrhosis. Nat. Rev. Gastroenterol. Hepatol. 2013, 10, 330-344. [CrossRef] [PubMed]

9. Romeo, S.; Kozlitina, J.; Xing, C.; Pertsemlidis, A.; Cox, D.; Pennacchio, L.A.; Boerwinkle, E.; Cohen, J.C.; Hobbs, H.H. Genetic variation in PNPLA3 confers susceptibility to nonalcoholic fatty liver disease. Nat. Genet. 2008, 40, 1461-1465. [CrossRef] [PubMed]

10. Sookoian, S.; Pirola, C.J. Meta-analysis of the influence of I148M variant of patatin-like phospholipase domain containing 3 gene (PNPLA3) on the susceptibility and histological severity of nonalcoholic fatty liver disease. Hepatology 2011, 53, 1883-1894. [CrossRef] [PubMed] 
11. Trepo, E.; Nahon, P.; Bontempi, G.; Valenti, L.; Falleti, E.; Nischalke, H.D.; Hamza, S.; Corradini, S.G.; Burza, M.A.; Guyot, E.; et al. Association between the PNPLA3 (rs738409 C>G) variant and hepatocellular carcinoma: Evidence from a meta-analysis of individual participant data. Hepatology 2014, 59, 2170-2177. [CrossRef] [PubMed]

12. Zhang, L.; You, W.; Zhang, H.; Peng, R.; Zhu, Q.; Yao, A.; Li, X.; Zhou, Y.; Wang, X.; Pu, L.; Wu, J. PNPLA3 polymorphisms (rs738409) and non-alcoholic fatty liver disease risk and related phenotypes: A meta-analysis. J. Gastroenterol. Hepatol. 2015, 30, 821-829. [CrossRef] [PubMed]

13. Yki-Jarvinen, H. Non-alcoholic fatty liver disease as a cause and a consequence of metabolic syndrome. Lancet Diabetes Endocrinol. 2014, 2, 901-910. [CrossRef]

14. Kozlitina, J.; Smagris, E.; Stender, S.; Nordestgaard, B.G.; Zhou, H.H.; Tybjaerg-Hansen, A.; Vogt, T.F.; Hobbs, H.H.; Cohen, J.C. Exome-wide association study identifies a TM6SF2 variant that confers susceptibility to nonalcoholic fatty liver disease. Nat. Genet. 2014, 46, 352-356. [CrossRef] [PubMed]

15. Zhou, Y.; Llaurado, G.; Oresic, M.; Hyotylainen, T.; Orho-Melander, M.; Yki-Jarvinen, H. Circulating triacylglycerol signatures and insulin sensitivity in NAFLD associated with the E167K variant in TM6SF2. J. Hepatol. 2015, 62, 657-663. [CrossRef] [PubMed]

16. Mahdessian, H.; Taxiarchis, A.; Popov, S.; Silveira, A.; Franco-Cereceda, A.; Hamsten, A.; Eriksson, P.; van't Hooft, F. TM6SF2 is a regulator of liver fat metabolism influencing triglyceride secretion and hepatic lipid droplet content. Proc. Natl. Acad. Sci. USA 2014, 111, 8913-8918. [CrossRef] [PubMed]

17. Lambert, J.E.; Ramos-Roman, M.A.; Browning, J.D.; Parks, E.J. Increased de novo lipogenesis is a distinct characteristic of individuals with nonalcoholic fatty liver disease. Gastroenterology 2014, 146, 726-735. [CrossRef] [PubMed]

18. Cani, P.D.; Osto, M.; Geurts, L.; Everard, A. Involvement of gut microbiota in the development of low-grade inflammation and type 2 diabetes associated with obesity. Gut Microbes 2012, 3, 279-288. [CrossRef] [PubMed]

19. Ekstedt, M.; Hagstrom, H.; Nasr, P.; Fredrikson, M.; Stal, P.; Kechagias, S.; Hultcrantz, R. Fibrosis stage is the strongest predictor for disease-specific mortality in NAFLD after up to 33 years of follow-up. Hepatology 2015, 61, 1547-1554. [CrossRef] [PubMed]

20. Singh, S.; Allen, A.M.; Wang, Z.; Prokop, L.J.; Murad, M.H.; Loomba, R. Fibrosis progression in nonalcoholic fatty liver $v s$. nonalcoholic steatohepatitis: A systematic review and meta-analysis of paired-biopsy studies. Clin. Gastroenterol. Hepatol. 2015, 13, 643-654. [CrossRef] [PubMed]

21. Seppala-Lindroos, A.; Vehkavaara, S.; Hakkinen, A.M.; Goto, T.; Westerbacka, J.; Sovijarvi, A.; Halavaara, J.; Yki-Järvinen, H. Fat accumulation in the liver is associated with defects in insulin suppression of glucose production and serum free fatty acids independent of obesity in normal men. J. Clin. Endocrinol. Metab. 2002, 87, 3023-3028. [CrossRef] [PubMed]

22. Adiels, M.; Westerbacka, J.; Soro-Paavonen, A.; Hakkinen, A.M.; Vehkavaara, S.; Caslake, M.J.; Packard, C.; Olofsson, S.O.; Yki-Järvinen, H.; Taskinen, M.R.; et al. Acute suppression of VLDL1 secretion rate by insulin is associated with hepatic fat content and insulin resistance. Diabetologia 2007, 50, 2356-2365. [CrossRef] [PubMed]

23. Tchernof, A.; Despres, J.P. Pathophysiology of human visceral obesity: An update. Physiol. Rev. 2013, 93, 359-404. [CrossRef] [PubMed]

24. Green, C.J.; Hodson, L. The influence of dietary fat on liver fat accumulation. Nutrients 2014, 6, 5018-5033. [CrossRef] [PubMed]

25. Westerbacka, J.; Lammi, K.; Hakkinen, A.M.; Rissanen, A.; Salminen, I.; Aro, A.; Yki-Järvinen, H. Dietary fat content modifies liver fat in overweight nondiabetic subjects. J. Clin. Endocrinol. Metab. 2005, 90, 2804-2809. [CrossRef] [PubMed]

26. Van Herpen, N.A.; Schrauwen-Hinderling, V.B.; Schaart, G.; Mensink, R.P.; Schrauwen, P. Three weeks on a high-fat diet increases intrahepatic lipid accumulation and decreases metabolic flexibility in healthy overweight men. J. Clin. Endocrinol. Metab. 2011, 96, E691-E695. [CrossRef] [PubMed]

27. Bjermo, H.; Iggman, D.; Kullberg, J.; Dahlman, I.; Johansson, L.; Persson, L.; Berglund, J.; Pulkki, K.; Basu, S.; Uusitupa, M.; et al. Effects of n-6 PUFAs compared with SFAs on liver fat, lipoproteins, and inflammation in abdominal obesity: A randomized controlled trial. Am. J. Clin. Nutr. 2012, 95, 1003-1012. [CrossRef] [PubMed] 
28. Bozzetto, L.; Prinster, A.; Annuzzi, G.; Costagliola, L.; Mangione, A.; Vitelli, A.; Mazzarella, R.; Longobardo, M.; Mancini, M.; Vigorito, C. Liver fat is reduced by an isoenergetic MUFA diet in a controlled randomized study in type 2 diabetic patients. Diabet. Care 2012, 35, 1429-1435. [CrossRef] [PubMed]

29. Utzschneider, K.M.; Bayer-Carter, J.L.; Arbuckle, M.D.; Tidwell, J.M.; Richards, T.L.; Craft, S. Beneficial effect of a weight-stable, low-fat/low-saturated fat/low-glycaemic index diet to reduce liver fat in older subjects. Br. J. Nutr. 2013, 109, 1096-1104. [CrossRef] [PubMed]

30. Ryan, M.C.; Itsiopoulos, C.; Thodis, T.; Ward, G.; Trost, N.; Hofferberth, S.; O'Dea, K.; Desmond, P.V.; Johnson, N.A.; Wilson, A.M. The Mediterranean diet improves hepatic steatosis and insulin sensitivity in individuals with non-alcoholic fatty liver disease. J. Hepatol. 2013, 59, 138-143. [CrossRef] [PubMed]

31. Kirk, E.; Reeds, D.N.; Finck, B.N.; Mayurranjan, S.M.; Patterson, B.W.; Klein, S. Dietary fat and carbohydrates differentially alter insulin sensitivity during caloric restriction. Gastroenterology 2009, 136, 1552-1560. [CrossRef] [PubMed]

32. Browning, J.D.; Baker, J.A.; Rogers, T.; Davis, J.; Satapati, S.; Burgess, S.C. Short-term weight loss and hepatic triglyceride reduction: Evidence of a metabolic advantage with dietary carbohydrate restriction. Am. J. Clin. Nutr. 2011, 93, 1048-1052. [CrossRef] [PubMed]

33. Haufe, S.; Engeli, S.; Kast, P.; Bohnke, J.; Utz, W.; Haas, V.; Hermsdorf, M.; Mähler, A.; Wiesner, S.; Birkenfeld, A.L.; et al. Randomized comparison of reduced fat and reduced carbohydrate hypocaloric diets on intrahepatic fat in overweight and obese human subjects. Hepatology 2011, 53, 1504-1514. [CrossRef] [PubMed]

34. Sobrecases, H.; Le, K.A.; Bortolotti, M.; Schneiter, P.; Ith, M.; Kreis, R.; Boesch, C.; Tappy, L. Effects of short-term overfeeding with fructose, fat and fructose plus fat on plasma and hepatic lipids in healthy men. Diabet. Metab. 2010, 36, 244-246. [CrossRef] [PubMed]

35. Rosqvist, F.; Iggman, D.; Kullberg, J.; Cedernaes, J.; Johansson, H.E.; Larsson, A.; Johansson, L.; Ahlström, H.; Arner, P.; Dahlman, I. Overfeeding polyunsaturated and saturated fat causes distinct effects on liver and visceral fat accumulation in humans. Diabetes 2014, 63, 2356-2368. [CrossRef] [PubMed]

36. Johnston, R.D.; Stephenson, M.C.; Crossland, H.; Cordon, S.M.; Palcidi, E.; Cox, E.F.; Taylor, M.A.; Aithal, G.P.; Macdonald, I.A. No difference between high-fructose and high-glucose diets on liver triacylglycerol or biochemistry in healthy overweight men. Gastroenterology 2013, 145, 1016-1025. [CrossRef] [PubMed]

37. Ngo Sock, E.T.; Le, K.A.; Ith, M.; Kreis, R.; Boesch, C.; Tappy, L. Effects of a short-term overfeeding with fructose or glucose in healthy young males. Br. J. Nutr. 2010, 103, 939-943. [CrossRef] [PubMed]

38. Silbernagel, G.; Machann, J.; Unmuth, S.; Schick, F.; Stefan, N.; Haring, H.U.; Fritsche, A. Effects of 4-week very-high-fructose/glucose diets on insulin sensitivity, visceral fat and intrahepatic lipids: An exploratory trial. Br. J. Nutr. 2011, 106, 79-86. [CrossRef] [PubMed]

39. Maersk, M.; Belza, A.; Stodkilde-Jorgensen, H.; Ringgaard, S.; Chabanova, E.; Thomsen, H.; Pedersen, S.B.; Astrup, A.; Richelsen, B. Sucrose-sweetened beverages increase fat storage in the liver, muscle, and visceral fat depot: A 6-mo randomized intervention study. Am. J. Clin. Nutr. 2012, 95, 283-289. [CrossRef] [PubMed]

40. Bravo, S.; Lowndes, J.; Sinnett, S.; Yu, Z.; Rippe, J. Consumption of sucrose and high-fructose corn syrup does not increase liver fat or ectopic fat deposition in muscles. Appl. Physiol. Nutr. Metab. 2013, 38, 681-688. [CrossRef] [PubMed]

41. Lecoultre, V.; Egli, L.; Carrel, G.; Theytaz, F.; Kreis, R.; Schneiter, P.; Boss, A.; Zwygart, K.; Le, K.-A.; Bortolotti, M.; et al. Effects of fructose and glucose overfeeding on hepatic insulin sensitivity and intrahepatic lipids in healthy humans. Obesity 2013, 21, 782-785. [CrossRef] [PubMed]

42. Thoma, C.; Day, C.P.; Trenell, M.I. Lifestyle interventions for the treatment of non-alcoholic fatty liver disease in adults: A systematic review. J. Hepatol. 2012, 56, 255-266. [CrossRef] [PubMed]

43. Dyson, J.; Day, C. Treatment of non-alcoholic fatty liver disease. Dig. Dis. 2014, 32, 597-604. [CrossRef] [PubMed]

44. Mummadi, R.R.; Kasturi, K.S.; Chennareddygari, S.; Sood, G.K. Effect of bariatric surgery on nonalcoholic fatty liver disease: Systematic review and meta-analysis. Clin. Gastroenterol. Hepatol. 2008, 6, 1396-1402. [CrossRef] [PubMed]

45. Chavez-Tapia, N.C.; Tellez-Avila, F.I.; Barrientos-Gutierrez, T.; Mendez-Sanchez, N.; Lizardi-Cervera, J.; Uribe, M. Bariatric surgery for non-alcoholic steatohepatitis in obese patients. The Cochrane database of systematic reviews. 2010, 1, CD007340. [CrossRef] [PubMed] 
46. Sevastianova, K.; Kotronen, A.; Gastaldelli, A.; Perttila, J.; Hakkarainen, A.; Lundbom, J.; Suojanen, L.; Orho-Melander, M.; Lundbom, N.; Ferrannini, E.; et al. Genetic variation in PNPLA3 (adiponutrin) confers sensitivity to weight loss-induced decrease in liver fat in humans. Am. J. Clin. Nutr. 2011, 94, 104-111. [CrossRef] [PubMed]

47. Shen, J.; Wong, G.L.; Chan, H.L.; Chan, R.S.; Chan, H.Y.; Chu, W.C.; Cheung, B.H.; Yeung, D.K.; Li, L.S.; Sea, M.M.; et al. PNPLA3 gene polymorphism and response to lifestyle modification in patients with nonalcoholic fatty liver disease. J. Gastroenterol. Hepatol. 2015, 30, 139-146. [CrossRef] [PubMed]

48. Bian, H.; Hakkarainen, A.; Lundbom, N.; Yki-Jarvinen, H. Effects of dietary interventions on liver volume in humans. Obesity 2014, 22, 989-995. [CrossRef] [PubMed]

49. Vessby, B.; Uusitupa, M.; Hermansen, K.; Riccardi, G.; Rivellese, A.A.; Tapsell, L.C.; Nälsén, C.; Berglund, L.; Louheranta, A.; Rasmussen, B.M.; et al. Substituting dietary saturated for monounsaturated fat impairs insulin sensitivity in healthy men and women: The KANWU Study. Diabetologia 2001, 44, 312-319. [CrossRef] [PubMed]

50. Riccardi, G.; Giacco, R.; Rivellese, A.A. Dietary fat, insulin sensitivity and the metabolic syndrome. Clin. Nutr. 2004, 23, 447-456. [CrossRef] [PubMed]

51. Jebb, S.A.; Lovegrove, J.A.; Griffin, B.A.; Frost, G.S.; Moore, C.S.; Chatfield, M.D.; Bluck, L.J.; Williams, C.M.; Thomas AB Sanders on behalf of the RISCK Study Group. Effect of changing the amount and type of fat and carbohydrate on insulin sensitivity and cardiovascular risk: The RISCK (Reading, Imperial, Surrey, Cambridge, and Kings) trial. Am. J. Clin. Nutr. 2010, 92, 748-758. [CrossRef] [PubMed]

52. Tappy, L.; Le, K.A. Metabolic effects of fructose and the worldwide increase in obesity. Physiol. Rev. 2010, 90, 23-46. [CrossRef] [PubMed]

53. Chung, M.; Ma, J.; Patel, K.; Berger, S.; Lau, J.; Lichtenstein, A.H. Fructose, high-fructose corn syrup, sucrose, and nonalcoholic fatty liver disease or indexes of liver health: A systematic review and meta-analysis. Am. J. Clin. Nutr. 2014, 100, 833-849. [CrossRef] [PubMed]

54. Le, K.A.; Ith, M.; Kreis, R.; Faeh, D.; Bortolotti, M.; Tran, C.; Boesch, C.; Tappy, L. Fructose overconsumption causes dyslipidemia and ectopic lipid deposition in healthy subjects with and without a family history of type 2 diabetes. Am. J. Clin. Nutr. 2009, 89, 1760-1765. [CrossRef] [PubMed]

55. Theytaz, F.; Noguchi, Y.; Egli, L.; Campos, V.; Buehler, T.; Hodson, L.; Patterson, B.W.; Nishikata, N.; Kreis, R.; Mittendorfer, B.; et al. Effects of supplementation with essential amino acids on intrahepatic lipid concentrations during fructose overfeeding in humans. Am. J. Clin. Nutr. 2012, 96, 1008-1016. [CrossRef] [PubMed]

56. Stanhope, K.L.; Schwarz, J.M.; Keim, N.L.; Griffen, S.C.; Bremer, A.A.; Graham, J.L.; Hatcher, B.; Cox, C.L.; Dyachenko, A.; Zhang, W.; et al. Consuming fructose-sweetened, not glucose-sweetened, beverages increases visceral adiposity and lipids and decreases insulin sensitivity in overweight/obese humans. J. Clin. Investig. 2009, 119, 1322-1334. [CrossRef] [PubMed]

57. Sanyal, A.J.; Chalasani, N.; Kowdley, K.V.; McCullough, A.; Diehl, A.M.; Bass, N.M.; Neuschwander-Tetri, B.A.; Lavine, J.E.; Tonascia, J.; Unalp, A.; et al. Pioglitazone, vitamin E, or placebo for nonalcoholic steatohepatitis. N. Engl. J. Med. 2010, 362, 1675-1685. [CrossRef] [PubMed]

58. Lavine, J.E.; Schwimmer, J.B.; van Natta, M.L.; Molleston, J.P.; Murray, K.F.; Rosenthal, P.; Abrams, S.H.; Scheimann, A.O.; Sanyal, A.J.; Chalasani, N.; et al. Effect of vitamin E or metformin for treatment of nonalcoholic fatty liver disease in children and adolescents: The TONIC randomized controlled trial. Jama 2011, 305, 1659-1668. [CrossRef] [PubMed]

59. Jacome-Sosa, M.M.; Parks, E.J. Fatty acid sources and their fluxes as they contribute to plasma triglyceride concentrations and fatty liver in humans. Curr. Opin. Lipidol. 2014, 25, 213-220. [CrossRef] [PubMed]

60. Donnelly, K.L.; Smith, C.I.; Schwarzenberg, S.J.; Jessurun, J.; Boldt, M.D.; Parks, E.J. Sources of fatty acids stored in liver and secreted via lipoproteins in patients with nonalcoholic fatty liver disease. J. Clin. Investig. 2005, 115, 1343-1351. [CrossRef] [PubMed]

61. Kotronen, A.; Juurinen, L.; Tiikkainen, M.; Vehkavaara, S.; Yki-Jarvinen, H. Increased liver fat, impaired insulin clearance, and hepatic and adipose tissue insulin resistance in type 2 diabetes. Gastroenterology 2008, 135, 122-130. [CrossRef] [PubMed]

62. Gastaldelli, A.; Cusi, K.; Pettiti, M.; Hardies, J.; Miyazaki, Y.; Berria, R.; Buzzigoli, E.; Sironi, A.M.; Cersosimo, E.; Ferrannini, E.; et al. Relationship between hepatic/visceral fat and hepatic insulin resistance in nondiabetic and type 2 diabetic subjects. Gastroenterology 2007, 133, 496-506. [CrossRef] [PubMed] 
63. Horowitz, J.F.; Coppack, S.W.; Paramore, D.; Cryer, P.E.; Zhao, G.; Klein, S. Effect of short-term fasting on lipid kinetics in lean and obese women. Am. J. Physiol. 1999, 276, E278-E284. [PubMed]

64. Rossmeislova, L.; Malisova, L.; Kracmerova, J.; Stich, V. Adaptation of human adipose tissue to hypocaloric diet. Int. J. Obes. 2013, 37, 640-650. [CrossRef] [PubMed]

65. Jensen, M.D. Diet effects on fatty acid metabolism in lean and obese humans. Am. J. Clin. Nutr. 1998, 67 (Suppl. 3), 531S-534S. [PubMed]

66. Schwarz, J.M.; Neese, R.A.; Turner, S.; Dare, D.; Hellerstein, M.K. Short-term alterations in carbohydrate energy intake in humans. Striking effects on hepatic glucose production, de novo lipogenesis, lipolysis, and whole-body fuel selection. J. Clin. Investig. 1995, 96, 2735-2743. [CrossRef] [PubMed]

67. Chong, M.F.; Hodson, L.; Bickerton, A.S.; Roberts, R.; Neville, M.; Karpe, F.; Frayn, K.N.; Fielding, B.A. Parallel activation of de novo lipogenesis and stearoyl-CoA desaturase activity after $3 \mathrm{~d}$ of high-carbohydrate feeding. Am. J. Clin. Nutr. 2008, 87, 817-823. [PubMed]

(C) 2015 by the author; licensee MDPI, Basel, Switzerland. This article is an open access article distributed under the terms and conditions of the Creative Commons by Attribution (CC-BY) license (http://creativecommons.org/licenses/by/4.0/). 